\title{
The antibacterial effect of B-pinene derived from Citrus aurantifolia peel against oral Streptococcus mutans ATCC 25175
}

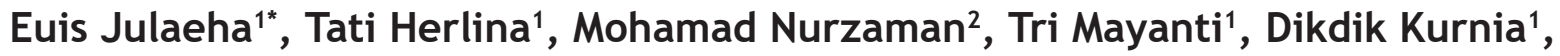 \\ Elizabeth Fitriana Sari ${ }^{3}$
}

\author{
'Department of Chemistry, Faculty of Mathematics and Natural Sciences Universitas Padjadjaran, \\ Indonesia \\ 2Department of Biology, Faculty of Mathematics and Natural Sciences Universitas Padjadjaran, \\ Indonesia \\ ${ }^{3}$ Dentistry and Oral Health Department, Latrobe Rural Health School, Australia
}

\begin{abstract}
Introduction: Streptococcus mutans has been known to play a major role in dental caries development. This tooth decay is the most common oral disease affecting people in the world. Hence, discovering the new herbal antibacterial agent seems to become more promising yet challenging. One of natural antibacterial source is the peel of Citrus aurantifolia, as it may contain antibacterial active compounds against pathogenic oral microbes. This study was aimed to isolate antibacterial compound from essential oil of Citrus aurantifolia and to analyse its antibacterial activity against oral Streptococcus mutans ATCC 25175. Methods: Type of research was laboratory experimental. The essential oil was isolated from peel of Citrus aurantifolia by hydro-distillation technique and further isolation of antibacterial compounds was conducted by combination column chromatography using organic solvent, and the structure was determined by UV-Vis, infrared (IR), 1D NMR of ${ }^{1} \mathrm{H}-,{ }^{13} \mathrm{C}-\mathrm{NMR}$ and DEPT $135^{\circ}$ in $\mathrm{CDCl} 3$ spectrometers methods. The antibacterial activity was tested against Streptococcus mutans ATCC 25175 using the KirbyBauer method. Results: $0.75 \%$ yield was obtained from the essential oil of peel Citrus aurantifolia and after purification, an antibacterial compound was identified as $B$-pinene with the molecular formula $\mathrm{C}_{10} \mathrm{H}_{16}$. Furthermore, the B-pinene from peel of Citrus aurantifolia exerted inhibition growth against Streptococcus mutans at concentration of 2000,1000 , and 500 ppm by showing respectively, inhibition values of $13.0,11.9$, and $11.6 \mathrm{~mm}$ on paper disk. Conclusion: In the present study, the essential oil of Citrus aurantifolia peel is proven to contain prospective antibacterial compound (B-pinene) that potentially can be used as natural antibacterial alternative choice to manage oral disease associated with Streptococcus mutans infection.
\end{abstract}

Keywords: Citrus aurantifolia; essential oil; B-pinene; Streptococcus mutans; antibacterial.

p-ISSN: 1979-0201; e-ISSN: 2549-6212; Available from: http://jurnal.unpad.ac.id/pjd/article/view/29200

DOI: $10.24198 / p j d . v o l 33$ no1.29200

Submission: Feb 26, 2018; Accepted: Mar 30, 2021; Published online: Mar 31, 2021

*Corresponding author: Euis Julaeha, Department of Chemistry, Faculty of Mathematics and Natural Sciences Universitas Padjadjaran, Indonesia Km 21, Jalan Raya Bandung Sumedang, Sumedang Regency, West Java, Indonesia, 45361. Phone: +62 815-7000-890; e-mail: euis.julaeha@unpad.ac.id 


\section{INTRODUCTION}

Dissolution of enamel minerals that leads to dental caries is recognized to take multiples steps to occur. This chronical process of caries development is influenced by microbial acid formation from the substrate, followed by the organic component destruction, and consequently form cavitation. ${ }^{1}$ Furthermore, bacteria play a big role in the incidence of caries. Oral Streptococcus mutans (S. mutans) is considered to be responsible for colonization in dental biofilm and known to support the attachment of other oral bacteria to the tooth enamel, and implicated in acid dissolution. ${ }^{2,3}$ In addition, S. mutans was found to be the most cariogenic oral Streptococcus and involved in plaque formation as well as dental caries initiation. ${ }^{4}$ The repeated administration of synthetic antimicrobial drugs has been causing drug resistance. ${ }^{5}$ For example, the prevalence of clindamycin resistance was found to be $37.8 \%$ and $5.5 \%$ towards S. mutans and S. sanguinis, respectively. ${ }^{5}$

Presently, there is minimal used of medicinal natural product in dentistry. The high number of dental caries prevalence in Indonesia and the increase of antibacterial drug resistance have generated the need to find a more bio-acceptable drug from natural product against dental caries. We considered to study lime or Jeruk nipis (Citrus aurantifolia) and its effect on S. mutans. Citrus genus easily grows in tropical regions in the northern and southern hemisphere. The fruits are well-known to have delicious taste, aromatic smell, and contains high vitamin C. These fruits are widely used in traditional medicine to treat cataracts, colds, sore throats, fevers, chest pain, earaches, headaches, stomach ailments, and edema. Also, there have been applications as antiseptic, anthelmintic, mosquito repellent, antiscurvy, digestion stimulant substance, and others. Furthermore, the Citrus juice and its essential oils are commonly used as daily drink, medicine, and cosmetics industries, for its medicinal properties and delightful smell.6,7,8,9 These Citrus fruits are extensively used worldwide, including lime or Citrus aurantifolia (C. aurantifolia that grows in numerous tropical and subtropical regions, and categorized as a polyembriony. ${ }^{10}$ Generally, we consume the pulp part of lime, while the peel is removed. It was reported that the peel of $C$. aurantifolia comprise of various benefits such as antibacterial effect. ${ }^{11}$ Lang et al. ${ }^{12}$ reported the active compounds that responsible as antibacterial in Citrus peels oil, encompassing the monoterpenes component. The essential oils generated from $C$. aurantifolia have been applied in mouthwash and showed the ability to inhibit S. mutans growth. It has been revealed that $C$. aurantifolia essential oils contain several compounds, however, the main compounds of C. aurantifolia essential oil include d-limonene, a-terpineol, terpinen-4-ol, and B-pinenesynthesis of lime oil (Citrus aurantifolia). ${ }^{13}$

This current study describes the isolation yield from C. aurantifolia essential oils, followed by the identification of antibacterial chemical structures, and its antibacterial susceptibility test against $S$. mutans. This study was aimed to isolate antibacterial compound from essential oil of Citrus aurantifolia and to analyze its antibacterial activity against bacteria Streptococcus mutans ATCC 25175.

\section{METHODS}

\section{Research materials and equipment}

Research Materials: Jeruk nipis (C. aurantifolia) was obtained from Gedebage Main Market, Bandung, Jawa Barat, Indonesia, and fruit was identified at The Plant Taxonomy Laboratory, Department of Biology, Faculty of Mathematics and Natural Sciences, Padjadjaran University. The chemicals comprised of various types of technical organic solvents (redistilled) and pro-analysts' grade, silica G 60 (70-230 mesh) and octadecylsilane (ODS RP-18) for column chromatography (CC), silica G $60 \mathrm{~F}_{254}$ for thin layer chromatography (TLC), f $10 \% \mathrm{H}_{2} \mathrm{SO}_{4}(\mathrm{v} / \mathrm{v})$ solution in ethanol as TLC coloring reagents. The oral $S$. mutans ATCC 25175 and required materials for antibacterial activity test were obtained from the Research Laboratory, Department of Chemistry, FMIPA, Universitas Padjadjaran.

Equipment: Buchi R 144 type rotary evaporator fortified with Buchi's B 169 vacuum system and open column chromatography apparatus. The isolates were identified using NMR JEOL type ECA 500 spectrometers with $500 \mathrm{MHz}$ magnetic field, mass spectrometer. 
Isolation of essential oil and antibacterial compounds from C. aurantifolia

The essential of peel part of $C$. aurantifolia was prepared and isolated using the hydro-distillation method. The sample of fruit peels $(1 \mathrm{~kg})$ was continuously distilled for 3 hours. Furthermore, the resulted essential oil was stored in dark vial bottles with lid tightly closed and stored them in a dry and cool place. This operation was repeated to attain sufficient amount of essential oil.

For isolation of active compound, the essential oil compound was separated through combination of various chromatographic techniques on normal (Silica G 60) and reverse phase (ODS RP18 ), eluted by variation organic mixture solvents of $n$-hexane and ethyl acetate with the polarity gradually being increased. All separation steps were guided and controlled by thin layer chromatography techniques, using $10 \%$ sulfuric acid stain reagent diluted in ethanol.

\section{Characterization of chemical structure of iso- late}

The structure of active compound was determined and identified by spectroscopic method using UVVis spectrometers (Perkin-Elmer brand type Lambda 35), infrared (IR) spectrometers, 1D NMR of ${ }^{1} \mathrm{H}$-, ${ }^{13} \mathrm{C}$-NMR and DEPT $135^{\circ}$ in $\mathrm{CDCl} 3$ as solvent at 125 and $500 \mathrm{Mhz}$ spectrometers methods, respectively.

\section{Antibacterial activitys test against S. mutans ATCC 25175}

The antibacterial activity of essential oils of peel part of $C$. aurantifolia were performed against S. mutans ATCC 25175 using the Kirby-Bauer Disk Diffusion method, with Mueller Hinton (MH) media agar. A total of one dose oral S. mutans ATCC 25175 from the stock was inoculated into a sterile test tube containing $4 \mathrm{~mL}$ of physiological $\mathrm{NaCl}$ suspension, to achieve a turbidity level of $1 / 2$ McFarland. Therefore, each unit was incubated at $37^{\circ} \mathrm{C}$ for $2 \times 16-18$ hours.

Cotton stick was dipped into S. mutans ATCC 25175 suspension and applied to the media surface before distributed evenly. Subsequently, $50 \mu \mathrm{L}$ of sample, chlorhexidine (positive control) and ethyl acetate (negative control) were dripped on paper disk and then placed on the blood agar medium. This was followed by incubation at $37^{\circ} \mathrm{C}$ for $2 \times 24$ hours.

\section{RESULTS}

\section{Isolation of essential oil and compound 1}

Fresh peel fruit $C$. aurantifolia $(1 \mathrm{~kg})$ was cut into small pieces and the essential oil compounds was extracted by hydro-distillation method for 3 hours to yield $7.523 \mathrm{~g}$ (or $0.75 \%$ ) of yellowish oil. For separation and purification of its active compounds, the resulted $7.523 \mathrm{~g}$ essential oil was subjected to column chromatographed on Silica $G$ 60 (230-400 mesh) and eluted with 10\% $n$-hexaneethyl acetate stepwise manner, respectively. The eluted fractions with $n$-hexane-ethyl acetate were by $6: 4$ to $5: 5$ being re-chromatographed on Silica G 60 (230-400 mesh) which eluted with $n$-hexane-ethyl acetate by $98: 2$, continuously. The pure compound was isolated as $3 \mathrm{mg}$ colorless oil, showed as single spot by 2D TLC analysis on Silica $G$ $60 \mathrm{~F}_{254}$ eluted with $n$-hexane-ethyl acetate (95:5) and $n$-hexane-chloroform (5:5), respectively.

\section{Structure determination of compound 1}

The structure of compound 1 was identified by comprehensive analysis of UV, IR, NMR, and MS spectral data. Compound 1 showed no absorption on UV light at $\lambda_{\max } 254$ and $365 \mathrm{~nm}$, respectively, those indication of no free electron pairs group in its structure. The IR spectrum of 1 indicated absorption signals at 2926, 1645, 1459, 1370 1390 , and $907 \mathrm{~cm}^{-1}$ those that corresponding to the present functional groups of $\mathrm{C}-\mathrm{H}$ aliphatic, $\mathrm{C}-\mathrm{H}$ olefinic; $\mathrm{C}-\mathrm{H}$ cyclic; gem dimethyl and bending $\mathrm{C}-\mathrm{H}$ of olefinic, respectively.

The ${ }^{1} \mathrm{H}-\mathrm{NMR}$ of compound 1 showed two olefinic proton $\left(s p^{2}\right)$ signals at 4.10 and $5.08 \mathrm{ppm}$, together with two methyl proton signals at 0.88 and $1.11 \mathrm{ppm}$, respectively. Further analysis, the ${ }^{13} \mathrm{C}$-NMR and DEPT $135^{\circ}$ indicated 10 carbon signals including 8 of $s p^{3}$ for two methyl at $22.9 \&$ $26.2 \mathrm{ppm}$, three methylene at $22.8,22.8 \& 27.0$ $\mathrm{ppm}$, two methines at 39.5 \& $55.0 \mathrm{ppm}$, and a quaternary carbon at $38.9 \mathrm{ppm}$, respectively. Two other olefinic $s p^{2}$ carbons were identified at 106.7 and $153.4 \mathrm{ppm}$. In order to determine molecular formula of 1 and to confirm with UV, IR and NMR data, the compound 1 was measured by TOF ESI$M S$, and spectra showed molecular ion peak $\left[\mathrm{M}+\mathrm{H}^{+}\right]$ at $\mathrm{m} / \mathrm{z}$ 135.4595. The compound 1 was predicted to have DBE of three which corresponding to one double bond and two cyclic rings. Based on the 
comprehensive analysis of all spectral data and confirmed with published papers, compound 1 was identified as monoterpenoid of B-pinene or identified as 6,6-Dimethyl-2-methylenebicyclo [3.1.1] heptane. The structure is shown in Figure $1.14,15,16$

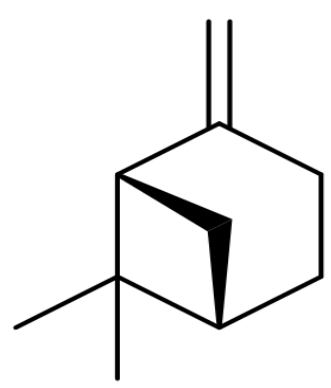

Figure 1. Structure of B-pinene (compound 1) Compound 1: ${ }^{13} \mathrm{C}-\mathrm{NMR}$ : סc 55.0 (C-1), 153.4 (C2), 22.8 (C-3), 22.8 (C-4), 39.5 (C-5), 38.9 (C-6), 27.0 (C-7), 26.2 (C-8), 22.9 (C-9), 106.7 (C-10). 'H-NMR: $\delta_{\mathrm{H}} 2.04(1 \mathrm{H}, \mathrm{m}, \mathrm{H}-1), 2.16(2 \mathrm{H}, \mathrm{m}, \mathrm{H}-3)$, $1.68(2 \mathrm{H}, \mathrm{m}, \mathrm{H}-4), 1.75(1 \mathrm{H}, \mathrm{m}, \mathrm{H}-5), 1.60(2 \mathrm{H}, \mathrm{m}$, $\mathrm{H}-7), 0.88(3 \mathrm{H}, \mathrm{m}, \mathrm{H}-8), 1.11(3 \mathrm{H}, \mathrm{m}, \mathrm{H}-9), 4.10$ $\left.\left(1 \mathrm{H}, \mathrm{m}, \mathrm{H}-10_{\mathrm{a}}\right) \& 5.08\left(1 \mathrm{H}, \mathrm{m}, \mathrm{H}-10_{\mathrm{b}}\right)\right)$

\section{Antibacterial activity of compound 1(B-pinene) against S. mutans ATCC 25175}

The bioactivity of the essential oil and compound 1 (B-pinene) isolated from C. aurantifolia as antibacterial agent was evaluated against $S$. mutans. The chlorhexidine and ethyl acetate were used as positive and negative controls, respectively. The assay result showed that compound 1(B-pinene) showed inhibition growth at all concentrations assay, while the essential oil of $C$. aurantifolia showed inhibition only at concentration of 1000 and 2000 ppm, as can be seen in Table 1.

\begin{tabular}{|c|c|c|c|c|c|c|}
\hline \multirow{3}{*}{$\begin{array}{l}\text { Samples } \\
\text { B-pinene }\end{array}$} & \multicolumn{6}{|c|}{ Concentrations (ppm) } \\
\hline & \multicolumn{2}{|c|}{2000} & \multicolumn{2}{|c|}{1000} & \multicolumn{2}{|c|}{500} \\
\hline & 13.1 & 13.1 & 11.9 & 11.9 & 11.6 & $\overline{11.6}$ \\
\hline Essential oil & 11.8 & 11.8 & 10.0 & 10.0 & - & - \\
\hline Ethyl acetate & 0 & 0 & 0 & 0 & 0 & 0 \\
\hline Chlorhexidine & 17.0 & 19.0 & & & & \\
\hline
\end{tabular}

\section{DISCUSSION}

This current study has successfully isolated the essential oil from peel of Citrus aurantifolia extract with an end yield of $0.75 \%$ (from $1 \mathrm{~kg}$ ). This result is weighed to be improved compared to previous reported studies which obtained the final extract in the range of $0.32-0.60 \% .{ }^{17}$

According to the antibacterial assay results that displayed in the Table 1, the essential oil of peel C. aurantifolia had an active antibacterial against S. mutans ATCC 25175 . The antibacterial activity demonstrated by the inhibition zones with values of 11.8 and $11.0 \mathrm{~mm}$ after exposed by essential oils at concentration of 2000 and 1000 ppm, respectively. The antibacterial activity finding is important to guide the separation and isolation process of its active antibacterial compounds.

Five essential oils extracted from C. nobilis, C. histryx, C.limon, C. aurantifolia, dan C. sinensis have been indicated to inhibit bacterial growth of S. mutans, and the most active antibacterial was recorded from C. aurantifolia. ${ }^{18}$ Another study by Lemes et al. ${ }^{19}$ found that the essential oils of leaves and fruits of $C$. aurantifolia were effective against Streptococcus mutans dan Lactobacillus case with identified chemicals compounds include limonene (77.5\%), linalool (20.1\%), citronellal $(14.5 \%)$ and citronellol (14.2\%), respectively. ${ }^{20}$

B-pinene compound exhibited antibacterial activity towards S. mutans ATCC 25175 showed inhibitions growth zones of $13.1,11.9$, and 11.6 $\mathrm{mm}$ at concentrations of 2000, 1000 and 500 ppm, respectively (Table 1). B-pinene compound was identified by separation and purifications of the peel C. aurantifolia essential oil using combinations of column chromatography methods. The antibacterial activity of the B-pinene appeared to be stronger than the essential oil itself, however, it was weaker compared to chlorhexidine as positive control.

According to the inhibition's growth zones measurement, the B-pinene showed slightly higher values compared with the inhibition growth exposed by essential oil. It was predicted that some of un-isolated compounds in essential oils also effected its antibacterial activity. Some studies indicated that the essential oils possess synergic and antagonist effect to each other that may lower its inhibition growth effect. ${ }^{21}$ The active compounds that have been revealed in essential oils such as citronellal, linalool and pinene of $C$. hystrix_were considered to have a synergic effect 
against_P. gingivalis, S. sanguinis and S. mutans, respectively. ${ }^{22}$

The B-pinene was also reported to have antimicrobe against Candida albicans, Cryptococcus neoformans, Rhizopus oryzae and methicillin-resistant Staphylococcus aureus (MRSA), ${ }^{23}$ However, our current study may be the first to report $B$-pinene isolated from peel of $C$. aurantifolia to have an antibacterial against oral S. mutans ATCC 25175. The previous study may strengthen our finding as the two derivative compounds of B-pinene which were identified as linalool and a-terpineol have been indicated to have antibacterial effect against periodontopathic and cariogenic bacteria. ${ }^{24}$

In addition, some studies showed that essential oil of $C$. aurantifolia not only possess antioxidant activity tested by DPPH assay, but also carry antibacterial agent against $S$. aureus and $E$. coli, respectively. ${ }^{25,26}$ The root part of C. aurantifolia exhibited antimicrobe against Staphylococcus aureus, Klebsiella pneumoniae, Proteus mirabilis, Pseudomonas aeruginosa, B-haemolytic, respectively. ${ }^{27}$ Based on these findings, we suggest that the essential oils which proven to contain B-pinene and their derivatives to be considered as a promising antibacterial agent from natural source to treat and cure oral disease cause by oral pathogen bacteria.

\section{CONCLUSION}

In the present study, the B-pinene compound was successfully isolated and identified from the essential oil of peel part of Jeruk nipis ( $C$. aurantifolia) which further exhibited antibacterial effect against S. mutans ATCC 25175. The antibacterial activity of this compound can be used to escort further isolation of other active compounds, as well as to determine an effective dose in further study using bioassay both in vitro and in vivo.

\section{ACKNOWLEDGMENTS}

The study was funded by Academic Leadership Grant (ALG), an internal grant from Universitas Padjadjaran (Grant No. 139/UN6.3/PM/2020).

\section{REFERENCES}

1. Neel EAA, Aljabo A, Strange A, Ibrahim $S$, Coathup $M$, Young AM, et al. Demineralizationremineralization dynamics in teeth and bone. Sonde. Int J Nanomedicine 2016;11:4743763.Published online 2016 Sep 19. DOI: 10. 10.2147/IJN.S107624

2. Lemos JA, PalmerSR, Zeng L, Wen ZT, KajfaszJK, Freires IA, et al. The Biology of Streptococcus mutans. Microbiol Spectr. 2019 Jan;7(1). DOI: 10.1128/microbiolspec.GPP3-0051-2018

3. Al-Kobaisi MF. Jawetz, Mellnick \& Adelberg's medical microbiology Kedokteran. Sultan Qaboos Univ Med J. 2007 Dec; 7(3):273-5.

4. Dziedzic A, Wojtyczka RD, Kubina R. Inhibition of oral streptococci growth induced by the complementary action of Berberine chloride and antibacterial compounds. Molecules 2015;20:13705-24. DOI: 10.3390/ molecules200813705.

5. Loyola-Rodriguez JP, Ponce-Diaz ME, Loyola-Leyva A, Garcia-Cortes JO, Medina-Solis CE, Contreras-Ramire AA et al. Determination and identification of antibiotic-resistant oral streptococci isolated from active dental infections in adult. Acta Odontol Scand 2018;76(4):229-35. DOI: 10.1080/00016357.2017.1405463.

6. Silvestre WP, Agostini F, Muniz LAR. Paulett GF. Fractionating of green mandarin (Citrus deliciosa Tenore) essential oil by vacuum fractional distillation. J Food Engineering. 2016;178:90-4. DOI: 10.1016/j. jfoodeng.2016.01.011

7. Sawamura M. Citrus Essential Oils Flavor and Fragrance. New Jersey: John Wiley \& Sons, Inc; 2010.

8. Al-aamri MS, Pharm B, Al-abousi NM, Pharm B, Al-jabri SS, Pharm B, Alam T, et al. Chemical composition and in-vitro antioxidant and antimicrobial activity of the essential oil of Citrus aurantifolia L. leaves grown in Eastern Oman. J Taibah Univ Med Sci 2018;13(2):10812. DOI: $10.1016 / j . j t u m e d .2017 .12 .002$

9. Spadaro F, Costa R, Circosta C, Occhiuto F. volatile composition and biological activity of key lime Citrus aurantifolia essential Oil. 
Nat Prod Commun 2019;7(11):1523-6. DOI: 10.1177/1934578X1200701128.

10. Spadaro F. Costa R, Circoosta C, Occhiuto F. Volatile Composition and Biological Activity of Key Lime Citrus aurantifolia Essential Oil. Natur Prod Communic 2012;7(11):1523-6. DOI:10.1177/1934578X1200701128

11. Mulyanti S, Dewi Sodja Laela DS, Julaeha E, Suwargiani AA, Aripin A. Formulation of mouth rinse from the essential oils of lime (Citrus aurantifolia) and its inhibitory efficacy on the growth of Streptococcus mutans in vitro. Padjadjaran J Dent 2020;32(1):39-47. DOI: 10.24198/pjd.vol32no1.25486

12. Lang G, Buchbauer G. A review on recent research results (2008-2010) on essential oils as antimicrobials and antifungals. A review. Flavour Frag J. 2012;27(1):13-39. DOI: $10.1002 /$ ffj.2082

13. Wahyudi T, Mulyawan AS, Kasipah C, Prayudie U, Julaeha E. Pembuatan mikrokapsul minyak jeruk (Citrus aurantifolia) untuk aplikasi pada penyempurnaan tekstil. Arena Tekstil 2017;32 (1):1-8. DOI: 10.31266/at.v32i1.2661

14. Bakiri A, Hubert J, Reynaud R, Lanthony S, Harakat D, Renault JH, et al. Computer-Aided 13C NMR Chemical Profiling of Crude Natural Extracts without Fractionation. J Natur Prod 2017;80(5):1387-96. DOI: 10.1021/acs. jnatprod.6b01063

15. Godevac D, Vujisic L, Vuckovic I, Vajs V, Sokovic M, Marin PD, Tesevic V. Composition and antimicrobial activity of the essential oil from Galatella linosyris (L.) Rchb. f. (Asteraceae). J Serb Chem Soc 2011;77(5):619-26. DOI: 10.2298/ JSC110915213G

16. Varkey TK, Baby S, Mathew J. Comparative chemical profiles of citrus aurantifolia essential oils from South India. Asian Journal of Chemistry. 2013:25(14):7871-5. DOI: 10.14233/ajchem.2013.14666

17. Choi O, Kim J, Park CG, Jinwoo Kim J. In vitro antibacterial activity and major bioactive components of Cinnamomum verum essential oils against cariogenic bacteria, Streptococcus mutans and Streptococcus sobrinus. Asian Pac J Tropic Biomed 2016;6(4):308-14. DOI: 10.1016/j.apjtb.2016.01.007

18. Aripin D, Julaeha E, Dardjan M, Cahyanto,
A. Chemical composition of Citrus spp. and oral antimicrobial effect of Citrus spp. peels essential oils against Streptococcus mutans. Padjadjaran J Dent 2015:27(1):1-11. DOI: 10.24198/pjd.vol27no1.26751

19. Lemes RS, Alves C, Estevam E, Santiago MB, Martins C, Santos T, et al. Chemical composition and antibacterial activity of essential oils from Citrus aurantifolia leaves and fruit peel against oral pathogenic bacteria. An Acad Bras Cienc 2018;90(2):1285-92. DOI: 10.1590/00013765201820170847

20. Alexa VT, Galuscan A, Popescu I, Tirziu E, Obistioiu D, Floare AD, et al. Synergistic/ antagonistic potential of natural preparations based on essential oils against streptococcus mutans from the oral cavity. Molecules. 2019;24:4043. DOI: 10.3390/ molecules24224043

21. Wongsariya K, Phanthong P, Bunyapraphatsara, $\mathrm{N}$, Vimol Srisukh V, Chomnawang MT. Synergistic interaction and mode of action of Citrus hystrix essential oil against bacteria causing periodontal diseases. Pharm Biol 2014;52(3): 273-80. DOI: 10.3109/13880209.2013.833948

22. Silva ACR, Lopes PM, Azevedo MMB, Costa DCM, Alviano CS, Alviano DS. Biological activities of a-pinene and B-pinene enantiomers. Molecules. 2012;25;17(6):6305-16. DOI: $10.3390 /$ molecules 17066305.

23. Park S, Lim YK, Freire MO, Cho, E, Jin D, Kook JK. Antimicrobial effect of linalool and a-terpineol against periodontopathic and cariogenic bacteria. Anaerobe 2012;18(3):36972. DOI: 10.1016/j.anaerobe.2012.04.001.

24. Al-Aamri MS, Al-Abousi NM, Al-Jabri SS, Alam T, Khan SA. Chemical composition and invitro antioxidant and antimicrobial activity of the essential oil of C. aurantifolianL. leaves grown in Eastern Oman. J Taibah Univ Med Sci 2018;13(2):108-11. DOI: 10.1016/j. jtumed.2017.12.002

25. Latif ARA, Hassan FG. The in vitro antibacterial activity of C. aurantifolia var Acidica fruits. Internat J Scie Res (IJSR) 2016;5(10):947-9.

26. Enejoh OS, Ogunyemi IO, Bala MS, Oruene IS, Suleiman MM. Ambali SF. Ethnomedical importance of C. aurantifolia (Christm) Swingle. The Pharma Innov J 2015;4(8):01-6. 